\title{
Socio-emotional education: paths to inspire studies, research and practices
}

\section{Educação socioemocional: caminhos para inspirar estudos, pesquisas e práticas}

\section{Educación socioemocional: maneras de inspirar estudios, investigación y prácticas}

\author{
Eugênia de Paula Benicio Cordeiro ${ }^{1}$ iD, Morgana Marcelly Costa Marques $^{2}$ iD, \\ Mayara Thayana Neves Costa ${ }^{2}$ iD
}

\author{
${ }^{1}$ Instituto Federal de Educação, Ciência e Tecnologia, Recife, Pernambuco, Brazil. \\ ${ }^{2}$ Universidade Federal de Pernambuco, Recife, Pernambuco, Brazil. \\ Corresponding author: \\ Eugênia de Paula Benício Cordeiro \\ Email: paulacordeiro@recife.ifpe.edu.br
}

How to cite: Cordeiro, E. P. C., Marques, M. M. C. \& Costa, M. T. N. (2021). Socio-emotional education: paths to inspire studies, research and practices. Revista Tempos e Espaços em Educação, 14(33), e13729.

http://dx.doi.org/10.20952/revtee.v14i33.13729

\begin{abstract}
This article presents findings of a bibliographic research which had as its scope identifying social and emotional skills proposed by different authors from this field. More specifically, it aimed to: classifying social and emotional skills by domains of competencies; detailing the skills related to selfawareness, focusing on the emotional dimension; proposing a lesson plan for promoting selfawareness in the classroom. The findings have shown that: by detailing social and emotional skills per competence, it may contribute to guide pedagogical activities based on theoretical pinpoints; deepening the theoretical foundations of emotions is essential for understanding the process of self-awareness; creating pedagogical sequences coherent and consistent with social and emotional development, requires the exercise of transposing theory into practice, respecting each educator's singularities according to his/her reality in class.
\end{abstract}

Keywords: Socio-emotional skills. Emotional education. Self-awareness

\section{RESUMO}

Este artigo apresenta os achados de uma pesquisa bibliográfica que teve por objetivo geral identificar habilidades socioemocionais propostas por diferentes teóricos da área. Mais especificamente, se propõe a: classificar as habilidades socioemocionais por domínios de competências; detalhar as habilidades relacionadas à competência do autoconhecimento, com foco 
na dimensão emocional; propor um plano de aula voltado para o autoconhecimento. Dentre os achados, é ressaltado que: o detalhamento das habilidades socioemocionais por competências pode contribuir para orientar atividades pedagógicas, oferecendo embasamento científico para o(a) educador(a); o aprofundamento teórico sobre o fenômeno emocional mostra-se essencial para a compreensão do autoconhecimento; a criação de sequências pedagógicas coerentes e consistentes com o desenvolvimento das habilidades socioemocionais requer o exercício da transposição da teoria para planejamento da prática, respeitando as singularidades de cada educador(a), estimulando-o(a) a adequar as atividades à sua realidade escolar.

Palavras-chave: Habilidades socioemocionais. Educação emocional. Autoconhecimento.

\section{RESUMEN}

Este artículo científico, presenta los resultados de una investigación bibliográfica que tuvo como objetivo identificar las habilidades socioemocionales propuestas por diferentes teóricos del campo. Más específicamente, propone: clasificar las habilidades socioemocionales por dominios de competencias; detallar las habilidades relacionadas con la competencia de autoconocimiento, centrándose en la dimensión emocional; proponer un plan de lección centrado en el autoconocimiento. Entre los hallazgos, destacamos: el detalle de las habilidades socioemocionales por competencias puede contribuir a guiar las actividades pedagógicas, ofreciendo una base científica para el educador; la profundización teórica sobre el fenómeno emocional se muestra esencial para comprender el autoconocimiento; La creación de secuencias pedagógicas coherentes y consistentes con el desarrollo de habilidades socioemocionales requiere el ejercicio de transponer la teoría a la planificación de la práctica respetando las singularidades de cada educador, animándolo a adaptar las actividades a la realidad de su escuela.

Palabras clave: Habilidades socioemocionales. Educación emocional. Autoconocimiento.

\section{INTRODUCTION}

Since the 1970s, guiding documents produced for education by the United Nations Educational, Scientific, and Cultural Organization (UNESCO) has guided actions to promote 'learning to be', as it is possible to observe in the report of the UNESCO-Paris International Commission for the Development of Education, presented to the world educational community in 1972 (Faure, 1972); as well as in the Report organized by Jacques Delors (Delors et al, 1997), in 1996, which established four fundamental pillars of education: learning to know, learning to do, learning to live with others, and learning to be. For the authors, this last pillar was considered the "[...] essential path that integrates the three preceding ones" (Delors et al., 1997, p. 90).

The 1990s were decisive in expanding the understanding of intelligence beyond cognizable reason, when the concept of Emotional Intelligence was first coined, giving rise to a new field of studies and research in education, dedicated to the development of relational skills and abilities ${ }^{1}$, aligned with the pillars of learning to be and living together.

This movement, consequently, has been influencing guiding documents for education, according to two more recent publications by UNESCO: the document entitled Global Citizenship Education: an Emerging Perspective, published in 2013 (UNESCO, 2013); and Education 2030:

\footnotetext{
${ }^{1}$ The perspective of competencies and abilities brought in this article is of a qualitative-transformative order, therefore, it rejects any alignment with utilitarian interests for the adequacy and/or manipulation of individuals for purposes other than those that value human formation through free self-formative, critical-transformative choice, preserving principles of respect and social justice.
} 
Incheon Declaration and Framework for Action, towards inclusive and equitable quality education and lifelong learning for all, as a result of the World Education Forum held in South Korea in May 2015.

The 2013 UNESCO document highlights key competencies for citizen education, such as knowledge and understanding of global trends and universal values (peace and human rights, diversity, justice, democracy, care, tolerance); cognitive skills for critical, creative, and innovative thinking, problem-solving and decision making; non-cognitive skills, such as empathy, openness to experiences and other perspectives, interpersonal/communication skills, and social networking, interactions with people from different backgrounds and knowledge; behavioral skills to launch and engage in proactive actions.

The 2015 document, Target 4.7 (p. 48), deals with the promotion of a culture of peace, citizenship, respect for diversity, and contributions to sustainable development. It signals strategies that favor the development of more robust assessment systems, which take into account cognitive, socioemotional, and behavioral assessment, to diagnose needs, inspiring the creation of new tools in various countries and regions.

In Brazil, advances can be observed in the 10 key competencies listed by the 2017 Common National Curriculum Base (BNCC), among which 3, equivalent to approximately one-third, are directly linked to intra- and interpersonal development, as will be seen below.

Despite finding a large number of studies and research (Alzina, González \& Navarro, 2015) varying in their denominations - Socio- and Emotional Learning, Emotional Intelligence, Emotional Education, Socio-emotional Skills, among others, it is possible to notice their affinities and complementarities. However, the transposition of their theories to the pedagogical practice involves limitations related to teacher training, considering that the current educators have hardly gone through a process of social and emotional education, not even stimulated to talk about it in Brazil! This leads to some questions: how to teach something for which we have no previous experience at all? How to study an area that demands from us a personal experience which implies the performance of self-knowledge exercises that are little practiced in the West? How can we create skillful means to talk about emotion and stimulate students to observe themselves? How can we change the way we feel, think, and act pedagogically? How can we adapt the theories and pedagogical practices of social and emotional education to our school reality? How to train educators to work in the field of social and emotional development?

The questions above reveal the hypothesis that motivated this research, that is: it is necessary to explore different strategies for studies, research, and practices in this new area of education, to point out skillful means that help take knowledge to the innermost layers of the human being, contributing to "learning to be and to live together". To this end, groups of researchereducators have been engaged in self-training processes and the training of other educational professionals. Such initiates in education arise as an alternative to find ways amid the many relational conflicts, often violent, which have led to psychological illnesses of teachers and students (Araújo, Pinho \& Masson, 2019).

In 2015, a study and research group was created in partnership with female teachers of a state high school in Pernambuco, to build knowledge from the reality experienced on the school floor, the fruit of the integration between academic theoretical foundation and practical experience in the classroom. This article, therefore, is the result of a bibliographic research work, which had as its main objective to present the results of a study aimed at identifying social and emotional skills proposed by different theoreticians in the area. More specifically, it proposes to: classify the socioemotional skills by skill domains; detail the skill related to self-knowledge, focusing on the emotional dimension; propose a lesson plan for the development of self-knowledge in the classroom. 


\section{SOCIAL AND EMOTIONAL LEARNING: FROM ITS EMERGENCE TO THE CHALLENGES OF SELF- TRAINING}

The 1990s were remarkable in the broadening of the understanding of intelligence, beyond logical-mathematical and linguistic reasoning. The theory of multiple intelligences, first presented by Howard Gardner, in 1983, in his book Structures of the Mind: the theory of multiple intelligences (1994), joins forces with the new concept coined in 1990 by American psychologists, Peter Salovey and John Mayer, in an article entitled Emotional Intelligence (Salovey \& Mayer, 1990), in which they define it as "the ability to monitor one's own and others' feelings and emotions, to discriminate among them and to use this information to guide one's actions (Mayer \& Salovey, 2004, p. 5, authors'emphasis).

In 1995, Daniel Goleman popularizes this concept in his first bestseller of a series: Emotional Intelligence: the revolutionary theory that redefines what it is to be intelligent (2007), and defines it as follows: [...] being able to motivate oneself and persist in the face of frustrations; control impulse and delay gratification; to regulate one's moods and keep distress from swamping the ability to think; to empathize and to hope (Goleman, 2007, p. 58).

It is interesting to note that Goleman (1997), while weaving theoretical contributions of a nascent field of research, advances when he perceives its applicability in numerous areas, such as corporate, family and marital, clinical medicine, and especially in education. The author points out: "[...] Educators, long disturbed by schoolchildren's lagging scores in math and reading, are realizing there is a diferent and more alarming deficiency: emotional illiteracy. [...]" (p.249). In that same decade, research showed a significant increase in arrests of American youth for violent crimes, leading scholars to conclude that the "[...] most common cause of disability among teenagers is mental illness. Symptoms of depression, whether mayor or minor, affect up to one third of teenagers; for girls, the incidence of depression doubles at puberty [...]. (p. 250)". He, therefore, devotes the last chapter of his book to encourage the teaching of emotions and cites a pioneering initiative at the time, the Science of Self Curriculum (McCown et al., 1998), created by Karen Stone McCown, which signals, "[...] Learning doesn't take place in isolation from kids' feelings. Being emotionally literate is as importat for learning as instruction in math and reading" (p. 278).

The emergence of a new field of research prompted American scientists to found, in 1994, the first scientific study and research organization in Social and Emotional Learning (SEL), the Collaborative for Academic, Social, and Emotional Learning (CASEL) ${ }^{2}$, committed to identifying best educational practices to maximize healthy social and emotional development in children, as well as academic achievement, ethical behavior, and citizenship. Comprised of a network of educators, scientists, and policymakers, CASEL strives to achieve the following goals: 1 . promote scientific advances in the field of SEL; 2 . translate scientific knowledge into effective educational practices; 3. disseminate information about scientifically sound SEL practices and strategies; 4. enhance training so that educators can effectively implement quality SEL-based programs, and 5 . Network to coordinate the efforts of all those involved in this area (Graczyk et al., 2000).

The interest in this new research area has been spreading in many other countries and continents, among which we highlight the initiatives developed by the Fundacion Marcelino Botin, based in Santander, Spain, since 2007, to conduct an international analysis of programs involving social and emotional education around the world, resulting in four publications available on its website $^{3}$ in the years 2008, 2011, 2013 and 2015.

In Brazil, initiatives in research in the area of emotional education are still sporadic and incipient in the public sector, as found in the doctoral thesis of Arantes (2019). However, it is

\footnotetext{
${ }^{2}$ More information: https://casel.org/. Accessed on: 6 May 2020.

3 Botín Foundation. Available at: https://www.fundacionbotin.org/educacion-contenidos/educacion-emocional-ysocial-analisis-internacional.html. Accessed on: 12 May 2020.
} 
possible to observe the emergence of Research Groups ${ }^{4}$ focused on Emotional Education, such as the Study and Research Group on Socio-emotional Skills and Values in Education (GHSEV), of the Federal Institute of Education, Science, and Technology of Pernambuco, Recife Campus; the Research Group on Emotional Education (GRUPPE) of the Universidade Federal Fronteira do Sul; and the Center for Emotional Education of the Education Center (NEEMOC) ${ }^{5}$ of the Federal University of Paraíba (UFPB).

Concerning public policies, advances toward emphasizing the importance of integrating the affective with the cognitive are underway. In December 2017, the Common National Curricular Base (BNCC) was approved, which highlights the commitment to comprehensive education, aiming at global human development, in the sense of integrating cognitive and affective dimensions, focused on the needs and interests of students. Therefore, it establishes 10 generic competencies, among which the last three are worth highlighting:

8. Know, appreciate, and take care of their physical and emotional health, recognizing their emotions and those of others, with self-criticism and the ability to deal with them and with group pressure.

9. Exercise empathy, dialogue, conflict resolution, and cooperation, making themselves respected and promoting respect for others, welcoming and valuing the diversity of individuals and social groups, their knowledge, identities, cultures, and potentialities, without prejudice of origin, ethnicity, gender, age, ability/need, religious belief or of any other nature, recognizing themselves as part of a collectivity to which they should be committed.

10. Act personally and collectively with autonomy, responsibility, flexibility, resilience, and determination, making decisions, based on the knowledge built in school, according to democratic, inclusive, sustainable, and solidarity-based ethical principles. (Brasil, 2017, p. 19, authors' translation)

For this theoretical study, the 5 domains of competencies established by CASEL (Weissberg et al., 2015) are taken as a basis, which will be further elaborated in Chart 1 (section 4.1.1), they are: self-knowledge, self-management, relational skills, social awareness, responsible decisionmaking.

The transposition of the theoretical basis of social and emotional competencies into pedagogical practice has proven challenging. For current generations of educators as training of this nature is scarce. These are life skills, which require experiential practice on the part of the educator. Social and Emotional Learning requires a new classroom culture. In this field of learning, the teacher is placed as someone who faces the same challenges in the relationships with himself (intrapersonal) and with others (interpersonal). Teachers and students become co-responsible for the cultivation of a healthy relational climate.

The First International Comparative Study on Language, Mathematics, and Associated Factors for Students in the Third and Fourth Years of Basic Education (PEIC) (UNESCO-Santiago, 2001), coordinated by the philosopher and educator Juan Casassus, found that school performance results from a multiplicity of effects arising from a complex combination of factors that influence students. The researchers concluded that the quality of learning is largely influenced by the quality of the processes that occur in the classroom (Casassus, 2009, p. 15). And the most important finding of the study was that learning can be favored by the emotional environment: "[...] First, it is important to note that the effect of this variable alone weighs more heavily on student outcomes than all the other factors put together" (Casassus, 2009, pp.156-157). This finding signals that the emotional dimension is something that depends on learning to be and live together essentially, a

\footnotetext{
4 For more information, access the Directory of Research Groups in Brazil/CNPq, available at: http://lattes.cnpq.br/web/dgp. Acesso em: 12 nov. 2019.

${ }^{5}$ For more information, available at: http://www.ce.ufpb.br/neemoc. Acesso em: 12 nov. 2019.
} 
knowledge that is still quite incipient in teacher education, and consequently, in the school as a whole (Cassassus, 2009).

Experience with the development of social-emotional education in public high schools, over the past five years, has shown the need to seek different theoretical lenses that lead to the detailing of skills to be developed. For example, the competence domain of self-knowledge presupposes the understanding of one's own emotions. This is a broad skill, which requires greater detailing, and may even be considered a sub-competency, given that it implies: learning to name emotions, learning to observe the emergence of emotions in their internal dynamics, recognizing the sensations provoked by emotions, interpreting the signs/insights arising from the manifestation of an emotion, observing the influence of a given emotion on thoughts, among other skills.

The experience with research in this area leads to the understanding that the more specific and detailed the socioemotional skills are, the more the educator can develop a work plan that is adequate to the reality of his/her classes, considering both the class hour and the pedagogical temporality of this learning process, exercising self-observation. It is essential, therefore, a previous formation of the educator, which requires him/her to commit to human self-formation (Röhr, 2013).

Based on theoretical-philosophical and psychological foundations (Röhr, 2013), it is necessary to understand the close relationship between the development of socio-emotional skills and personal practice, so that we consciously establish coherence between feeling, thinking, and acting.

Thus, this article seeks to share paths of study, research, and self-training to benefit other educators-researchers who intend to enter this developing area in Brazil. Offering ready-made materials to educators, without giving them time to appropriate the knowledge, may lead the teaching of Social and Emotional Skills (SES) to discredit or to become just another transmissive process, motivated by "encouraging" dynamics, but little to transform the emotional climate in the classroom.

It is necessary to learn to quiet down and look inside oneself with attention, or better yet, to exercise attentiveness (Ekman, 2011), to pay attention to emotional signals, or even learn to regulate impulses, for example. It is not just a matter of playing "emotions", but of understanding emotional maturation (Casassus, 2009) through one's own experience. The quest to develop this in research groups leads to the realization of how challenging it is to become more aware of how we feel, think and act. Learning to self-evaluate is not part of our culture or our education. It is something uncommon in the Brazilian school culture. Socioemotional skills become a global phenomenon at school when adopted in-depth, involving: teachers, students, managers, and family. But it is necessary to start somewhere, and it has to be the one who is responsible for the pedagogical task: the educator! (Röhr, 2013).

The sócio-emotional challenges allied to the process of self-training require a deeper understanding of the emotional phenomenon, which will be presented below in the light of one of the greatest researchers of the language of emotions, the psychologist who, for the first time, scientifically proved the universality of emotions: Paul Ekman (2011).

\section{UNDERSTANDING THE EMOTIONAL PHENOMENON}

The publication of the book Emotions Revealed in 2003, by the American psychologist Paul Ekman (translated into Portuguese in 2011), brought an important contribution to the field of study of emotions. Knowing the theory is of great value for the scientific appropriation of the theme and construction of a knowledge base to support any proposal for intervention in the emotional area, so we dedicate ourselves to present some points addressed by the author (Ekman, 2011).

Emotions, according to Ekman (2011), exist to get our attention and mobilize us to deal with issues that affect our well-being. The arousal of an emotion depends on the recognition of events 
previously registered in our mind, i.e. triggers, and may be related to the survival of our species or the experiences of each person. Unprecedented scenes that we witness are interpreted and qualified according to the effect they have caused us, and this register will become an emotional alert. Each time we come across a fact that refers to these records, the emotion associated with it will be triggered.

The set of triggers constitutes na emotion alert database. To this previous information, individual elaborations are constantly added, coming from the experiences we have in life, which continuously update the individual's database.

Ekman (2011) points out that emotions generally arise by automatic appraising mechanism, the self-evaluators, which are fundamental for quickly dealing with situations that affect our wellbeing. They are continual "[...] examining what was important for survival not only in our individual lives but also in the lives of hunter-gatherer ancestors" (Ekman, 2011, p. 46).

While this is the most common route, the author describes eight more pathways to activate an emotion: 1) reflective appraising (ibid, p.48) - more elaborate, it can move us when the understanding generated by it corresponds to a record of our emotional alertness database. 2) the memory of "remembering a past emotional scene" (ibid, p.49), spontaneous or deliberate, has the power to provoke emotions, similar or different from those experienced in the original situation. 3 ) "imagination" (ibid, p.50) makes us create scenes that can elicit an emotional reaction. 4) "talk about past emotional experiences" (ibid, p.50) can also make us relive emotions. 5) "empathy" (ibid, p.51), identifying with another's emotional reaction can make us share the emotion or feel a distinct one. 6) "others instructing us about what to be emotional about" (ibid, p.51) is someone's guidance on how to feel when faced with a certain event. The degree of a person's influence and the intensity of the emotion involved can cause the other to reproduce triggers and become emotional when faced with analogous situations. 7) the "violation of social norms" (ibid, p.52) can generate different emotions, according to the type of rule and the person breaking it. 8) "voluntarily assuming the appearance of an emotion" (ibid, p.52), reproducing universal expressions to experience it.

Aware of these paths, one should not establish an evaluative relationship with emotions, classifying them as positive or negative, accepting some, or rejecting others. By considering them as reactions, orchestrated by our experiences as a whole, they can be seen as clues to the understanding of our self/ego, as being active in the world, and for this reason, they must first be accepted and then understood.

When new emotional triggers are incorporated into our records, they cannot be erased, because "our emotional system is designed to maintain triggers, not to get rid of them, mobilizing emotional responses without thought. We are biologically built not to interrupt them" (Ekman, 2011, p. 61). Nevertheless, the author points out that, through conscious effort, it is possible to learn to create new patterns to disconnect or soften the link between certain triggers and our registers, avoiding emotions that trigger inappropriate actions. This realization is very encouraging for educational actions!

Knowing, then, that we cannot control the emergence of emotions, but the maturing in the way we deal with them can be stimulated by pedagogical actions. It is important to understand them to accept them, observe their effects, interpret their messages, and regulate actions that lead to conflictive, violent, and destructive processes. About this issue, Ekman (2011) explains that, to the extent that we are attentive to emotional sensations, even when overwhelmed by an emotion, it is possible to learn to moderate expressions, actions, or words, avoiding excesses.

There is no ready recipe, but the improvement of some skills and knowledge about emotions can provide a more balanced and harmonious life. Thus, Ekman (2011) emphasizes four basic skills: 1) become more aware of the moment when you are becoming emotional before you speak or act; 2) choose how you behave when you become emotional, achieving your goals without harming others 3 ) become more sensitive to how others are feeling; 4) use carefully the information you 
acquire about the feelings of others. The exercises and practices described in his book are invaluable in developing these skills.

The educator's pedagogical task, in this case, is to appropriate this knowledge, not only in a cognitive way but as a whole, practicing and experiencing it in real life. Only then will he be able to guide, with property, other people on this same path, going beyond the transmission of information. By offering opportunities for students to experience the emotional phenomenon in all its dimensions, we hope to open the way for them to take responsibility for their balance, oriented towards shared well-being.

\section{METHODOLOGICAL PATHS AND FINDINGS}

Bibliographic research (Gil, 2002) and thematic analysis (Minayo,1992) were the guiding methods of this study. The bibliographic research as an investigation "of the available record, resulting from previous research, in printed documents, such as books, articles, theses, etc." (Severino, 2007, p. 122), was fundamental to know the course of studies developed in the area of Socio-emotional Education, allowing to broaden the understanding on the subject and integrate concepts from various authors, contributing to a more detailed characterization of the competencies established by CASEL (Weisseberg et al., 2015): self-knowledge, self-management, relational skills, social awareness, and responsible decision-making.

Within the scope of bibliographic research, Gil (2002) suggests some steps, which were adopted along the way. From 'choice of topic' - sócio-emotional skills - we proceeded to the 'preliminary literature survey', arriving at 'formulation of the research problem': how can different theoretical perspectives illuminate the apprehension of sócio-emotional skills in the constitution of a domain of competence? Next, a 'tentative subject plan' was drawn up for the search of bibliographic 'sources' to arrive at an in-depth understanding of sócio-emotional skills. An "exploratory and selective reading" was then carried out to choose the works of interest for the research.

Once the corpus of the research was constituted, the exploration of the material began, adopting criteria that favored clarity and objectivity of the authors in describing socioemotional skills to avoid personal preferences of the researchers, always looking for the set of relationships around the investigated theme to identify the presence of nuclei of meaning (Minayo, 1992) in the selected texts. They were categorized into five domains of social and emotional competencies, according to Charts 1 (section 4.1.1) and 2 (section 4.2.1).

\section{First moment}

The studies began first with the search for theorists of expression in the area of social and emotional development, such as Roger Weissberg, Joseph Allen Durlak, Celene Dominitrovich, and Thomas Gullotta, members of CASEL, who edited the book entitled Handbook of Social and Emotional Learning: research and practice, in 2015; Juan Cassassus, Ph.D. in the sociology of education, who directs several training programs in emotional education and wrote, in 2017, the theoretical essay: Uma introducción a la Educación Emocional; Patricia Graczyk et al. (2000), responsible for the article Criteria for Evaluating the quality of school-based social and emotional learning programs, in which the authors present a framework categorizing key competencies for Socio-emotional Learning (SEL).

The corpus of the study was constructed from the thematic analysis method, considering how clearly the authors define and describe social-emotional skills. Exploring the material, five categories listed by CASEL (Weissberg et al., 2015) were chosen for classification and aggregation of 
the definitions collected, they are self-knowledge, self-management, relational skills, social awareness, and responsible decision-making. According to guidelines from Graczyk et al. (2000),

The identification of critical SEL competencies represents the first step in the process of facilitating students' social and emotional development. However, the way these competencies are taught is also very important because students need to be motivated to learn about and to use the competencies in their everyday lives. [...] (p. 399).

Once the competencies considered key was identified, descriptions and definitions were investigated for each of them, organizing them as elaborated in Table 1 below:

\section{Results of the thematic analysis by domains of competencies}

Chart 1 shows the results of the thematic analysis process, grouping socioemotional skills by competence domains.

Chat 1. Breakdown of sócio-emotional skills by domains of competence

\section{SELF-KNOWLEDGE}

Being still, observing the inner dynamics, and recognizing how thoughts, feelings, and actions are interconnected;

> Being aware: perceiving, naming, and understanding one's own emotions, personal goals, and values, and discerning between what is healthy and constructive and what is conflicting and stressful;

$>$ Recognize the existence of the emotional world, understanding it as a bridge between what is inside and what is outside of us;

$>$ Be sensitive to one's feelings and value emotional well-being;

$>$ Accurately access your qualities and limitations, and recognize, in your emotional style, what needs to be overcome and improved;

Recognize your ethical values, those that need to be cultivated, and commit to them.

\section{SELF MANAGEMENT}

$>$ Develop skills and attitudes that facilitate the ability to regulate emotions and behaviors, such as delaying gratification, managing stress, and controlling impulses;

$>$ Develop the ability to remain attentive, listening, pondering, and making sense of emotions that arise, understanding how our sensations guide our outlook;

Monitor the attunement with the other's emotionality to act coherently with it;

$>$ Cultivate the emotions that allow well-being and tranquility in order not to act compulsively;

$>$ Manage the projection of what we feel in others;

$>$ Persevere amid challenges to achieve personal and educational goals.

\section{SOCIAL AWARENESS}

$>$ Taking the perspective of those who have a different historical or cultural background seeking to develop compassion;

$>$ Accepting and considering individual and group differences, as well as valuing the rights of all people

$>$ Connecting with, welcoming, and supporting others;

$>$ Understand social norms of behavior and critically evaluate socio-cultural as well as media messages on social norms and personal behavior;

$>$ Recognize the resources and supports of family, school, and community and seek to contribute to their improvement;

Act following social norms, but resist inappropriate social pressure.

RELATIONAL SKILLS

$>$ Develop the ability to listen actively, attentively, and compassionately; 
$>$ Open to others, seeking intimacy, sharing experience, being open to giving and receiving affection, establishing and maintaining healthy and rewarding relationships;

$>$ To perceive accurately the perspectives of others. Becoming aware that the other feels similarly to us;

$>$ Initiating and sustaining conversations, expressing one's thoughts and feelings clearly both verbally and nonverbally, and demonstrating to others that they have been properly understood (expressive communication);

$>$ Pay attention to others when they express themselves verbally and non-verbally, to assimilate the messages conveyed accurately (receptive communication);

$>$ Understand and analyze the circumstances that arouse emotions in others;

$>$ Cooperate, take turns and share within a two-way or group relationship;

$>$ Resolve conflicts peacefully, considering the perspectives and feelings of others;

$>$ Seek help when needed, as well as provide support and assistance.

\section{RESPONSIBLE DECISION-MAKING}

$>$ Develop the ability to think and decide courses of action;

$>$ Identify situations that require a solution or decision and assess risks, barriers, and resources;

$>$ Set realistic goals and develop solutions based on reliable information;

$>$ Consider ethical standards, safety, and precise norms for risky behavior;

$>$ Consider the health and well-being of self and others to make constructive choices regarding personal behavior and social interactions;

$>$ Choosing to be right, just, charitable, and compassionate, and to adopt safe, healthy, and ethical behaviors;

$>$ To feel optimistic and prepared to face the challenges of everyday life;

$>$ To take responsibility for what we do with our sensations, emotions, and thoughts.

\section{RELATIONAL SKILLS}

$>$ Develop the ability to listen actively, attentively, and compassionately;

$>$ Open to others, seeking intimacy, sharing experience, being open to giving and receiving affection, establishing and maintaining healthy and rewarding relationships;

$>$ To perceive accurately the perspectives of others. Becoming aware that the other feels similarly to us;

$>$ Initiating and sustaining conversations, expressing one's thoughts and feelings clearly both verbally and nonverbally, and demonstrating to others that they have been properly understood (expressive communication)

$>$ Pay attention to others when they express themselves verbally and non-verbally, to assimilate the messages conveyed accurately (receptive communication);

$>$ Understand and analyze the circumstances that arouse emotions in others;

$>$ Cooperate, take turns and share within a two-way or group relationship;

$>$ Resolve conflicts peacefully, considering the perspectives and feelings of others;

$>$ Seek help when needed, as well as provide support and assistance.

\section{RESPONSIBLE DECISION-MAKING}

$>$ Develop the ability to think and decide courses of action;

$>$ Identify situations that require a solution or decision and assess risks, barriers, and resources;

$>$ Set realistic goals and develop solutions based on reliable information;

$>$ Consider ethical standards, safety, and precise norms for risky behavior;

$>$ Consider the health and well-being of self and others to make constructive choices regarding personal behavior and social interactions.

Source: Adapted by the authors (2020) from Weissberg et al., 2015; Graczyk et al., 2000; Cassasus, 2017

The assumption that the more detailed the skills, the greater clarity the educator will have when planning their lessons, served as a guide for the investigative look. At the same time, the 
educator himself needs to understand where to start practicing social-emotional skills. This thematic study can be carried out by any researcher who is interested in the area and, as he/she reads, tries to identify social and emotional skills, relating them to a certain competence.

\section{Second Stage}

After the exhaustive search for definitions that would bring more clarity and detail to socioemotional skills, the next step was to search for more specifics about the functioning of emotions. To achieve greater objectivity, the identification of actions and skills closer to the practice guided the intention to contribute to the educator or trainer in the development of his or her activities. Therefore, in this second moment, the book by Paul Ekman, entitled The Language of Emotions (2011), was selected by the group of researchers. The same thematic analysis methodology was adopted in the reading of this book, performing the associative grouping of socioemotional skills with their respective domains of competence, according to Chart 2.

\section{Results of the thematic analysis focused on the domain of self-knowledge}

Having presented, in general terms, the theory of Ekman (2011) in section 3, it was observed that the deepening of the author concerning the emotional phenomenon has expanded the set of possible skills for each competence. Therefore, another level of classification was deemed pertinent, given the observation of different dimensions for the emotional phenomenon, related to feeling, thinking, and acting.

Considering that space here is insufficient to present all the surveys carried out, it was necessary to opt for sharing a synthesis of the findings of our thematic analysis in the scope of selfknowledge, understanding this as the starting point in the movement of appropriation of the emotional phenomenon. To facilitate the organization of the abilities related to self-knowledge, three dimensions were established as sub-competencies of self-knowledge: attentiveness, understanding, and action (Chart 2).

Chart 2. Self-knowledge in the light of the emotional phenomenon

\begin{tabular}{|l|}
\hline SELF-KNOWLEDGE \\
\hline Attentiveness (feeling) \\
\hline $\begin{array}{l}\text { Becoming more aware of the moment when you are being affected by emotion or more emotions, } \\
\text { observing the sensations, what changes in your body and your consciousness; }\end{array}$ \\
$>\quad$ Observe the emotional signals that emerge almost instantaneously at the onset of each emotion \\
(anger, fear, sadness, joy, among others) \\
$>\quad$ Identify what emotions we provoke in others by observing changes in facial expressions and changes \\
in tone of voice; \\
$>\quad$ Concentrate on what the feelings want. \\
\hline Understanding (thinking) \\
\hline$>$ Identify places, situations, and people that make us emotional \\
$>\quad$ Understand the messages of the emotions; \\
$>\quad$ Understand the reasons that triggered the emotions; \\
$>\quad$ Analyze emotional episodes afterward, to develop the habit of thoughtfulness; \\
$>\quad$ Know your emotional alertness database to evaluate and update the data; \\
$>\quad$ Recognize and understand your triggers and mood/humor states that promote irritability, anxiety, and \\
introversion and/or enable well-being, balance, and satisfaction;
\end{tabular}


$>$ Identify inappropriate responses to things that have irritated, frightened, or disgusted you before. Reactions that, at this point, you consider incompatible with your adult life;

$>$ Recognize and understand inappropriate emotional reactions of disproportionate intensity;

\section{Action}

$>$ Appropriately demonstrate emotion;

$>$ Experience our emotions, have concerns about what happens as we behave.

$>$ Know and take responsibility for what we provoke in others

$>$ Exercising responsible decision making

Source: Adapted by the authors (2020) from Paul Ekman (2011)

Based on the above findings, a lesson plan proposal emerged to inspire educators in this process of transposing theory into practice.

\section{LESSON PLAN PROPOSAL FOR EMOTIONAL EDUCATION}

Based on the bibliographic studies and thematic analyses carried out, a proposed lesson plan will be presented in this section to inspire the transposition of theory into pedagogical practice, focusing on an introduction to self-knowledge.

According to Weissberg et al. (2015), educational approaches for promoting socio-emotional skills require four elements to be present:

(1) Sequenced: connected and coordinated set of activities to foster skills development; (2) Active: active forms of learning to help students master new skills; (3) Focused: a component that emphasizes developing personal and social skills; and (4) Explicit: targeting specific social and emotional skills (Durlark et al. apud Weissberg et al., 2015, p. 7, emphasis in the original).

Following the guidelines of Weissberg et al. (2015), a sequence is proposed from the following themes: 1) introduction to self-knowledge; 2) emotions and body sensations; 3 ) messages from emotions; 4) emotional episodes; 5) the awakening of emotion; 6) emotional alerts; 7) inappropriate emotional reactions; 8) attention to emotions. These modules reflect central issues discussed by Ekman (2011). Working on each of these aspects individually tends to ensure a deeper and more complete approach, and aims to develop skills gradually.

Below, as an example, a proposed lesson plan is presented. It is worth pointing out that the educator needs to structure his action according to the needs and reality of his students. It is important that from the plan it is possible to: investigate the level of knowledge and intimacy of the participants with the proposed theme; create spaces for listening, debate, and welcoming; develop activities in which the participants take on the leading role; present the concepts in a contextualized manner; and finally, encourage reflection and application, in everyday life, of what was experienced during each meeting.

Chart 3. Proposal for a lesson plan about self-knowledge

TARGET PUBLIC: Adolescents;

\section{MEETING 1: INTRODUCTION TO SELF-KNOWLEDGE}

DURATION: 1 hour;

GENERAL OBJECTIVE: to raise awareness of the importance of self-knowledge;

SPECIFIC OBJECTIVES: to encourage students to become quiet; to promote reflections about themselves and their lives; 
MATERIALS: a sheet of paper, pencil

\section{SUGGESTION FOR THE ACTIVITY (STEP BY STEP):}

1. Conversation about self-knowledge (10 minutes) - the conversation in a circle, guided by questions to investigate the students' level of awareness and understanding of self-knowledge: What is self-knowledge? How do you develop it? Do you know yourself? How do you get to know yourself?

2. Dynamics "Me and my life" (30min) - Ask the participants to draw a square and divide it into four parts. In the first square write "past", in the second "present", in the third "future" and the fourth nothing. Draw a picture that represents you in all three moments. In pairs, the students show their drawings to their classmates, to talk about: "What do you see? What do you feel? What do you think? After each person talks about their perceptions of the other's drawings, both talk freely about what they need to do today to achieve what they want for the future. Finally, they write down in the empty quadrant a synthesis of what they consider most relevant from this conversation.

3. Storytelling (10 minutes) - tell a story related to self-knowledge to demonstrate the importance of looking inside yourself, paying attention to your emotions, trying to interpret them. Take the opportunity to ask what they understand about emotions. Try to explore the skills listed above according to the story chosen.

4. Quieting (5 minutes) - ask the participants to close their eyes and reflect for three minutes on the content of the story. What did they feel? How did the characters feel? What did they think? How do they evaluate the characters' actions?

5. Homework exercise and final moment (5 minutes) - ask the participants, over the next few days, to try to perceive themselves and identify moments in which they see themselves in contact with themselves. Close by asking each person to speak a word that defines the day's encounter.

Source: The authors (2020)

\section{FINAL CONSIDERATIONS}

This research work was an attempt to promote greater theoretical awareness about social and emotional skills for the beginning of pedagogical practice, and at the same time to offer clues about how to follow this path of study and research for the construction of a practice. The systematization of theoretical knowledge, associated with a suggested lesson plan in the school space, was a way to help educators in their pedagogical task of raising awareness and guiding their students in the conscious development of their humanization process. There was no intention of establishing an application model, but only to illustrate the reflection of theory in the planning for the pedagogical practice, leaving room for creation and performance of the educator, according to the specificities of their educational context.

From this investigative effort, it was possible to see that the theoretical field related to social and emotional education has been receiving more and more attention, however, the experience of the knowledge produced by the area needs to overcome several obstacles to be present in practical life. Differently, when we apply, practice, and experience the knowledge in our relationships, it is possible to understand the contents from our own experiences.

The initial challenge is to awaken the educator for this need because only from his or her effort in building a path of internalization, which allows the experience of this knowledge in his or her feeling, thinking, and acting, will it be possible to undertake the task of guiding others in this same process. Committing to self-training in the development of social and emotional skills is an indispensable task to maintain coherence between what is being proposed and the practice in relationships. It is hoped, therefore, that the sharing of this path of study and research may contribute to the process of self-knowledge of the educators who are interested in this area, and that this maturing may be reflected in the quality of the relationships established with the students. 
To conclude, the findings of this research can be summarized as follows: theoretical deepening is fundamental for the creation of coherent and consistent pedagogical sequences for the development of socio-emotional skills; detailing of socio-emotional skills contributes to guiding pedagogical activities, offering a scientific basis to the educator; the exercise of transposing theory into practice planning respects the singularities of each educator, stimulating him/her to adapt the activities to his/her school reality.

Authors' Contributions: Eugênia de Paula Cordeiro: conception and design, acquisition of data, analysis and interpretation of data, drafting the article, critical review of important intellectual contente; Morgana Marcelly C. Marques: acquisition of data, analysis and interpretation of data, drafting the article, critical review of important intellectual contente; Mayara T. N. Costa: acquisition of data, analysis and interpretation of data. All authors have read and approved the final version of the manuscript.

Ethics Approval: Not applicable.

Acknowledgments: Not applicable.

\section{REFERENCES}

Alzina, R. B.; González, J. C. P. \& Navarro, E. G. (2015). Inteligencia emocional en educación. Madri: Editorial Sintesis.

Arantes, M. M. (2019). Educação Emocional Integral: análise de uma proosta formativa continuada de estudantes e professores em uma escola pública de Pernambuco. 274f. Tese (Doutorado em Educação) - Universidade Federal de Pernambuco. Recife-PE.

Araújo, T. M.; Pinho, P. S. \& Masson, M. L. V. (2018). Trabalho e saúde de professoras e professores no Brasil: reflexões sobre trajetórias das investigações, avanços e desafios. Cad. Saúde Pública, Rio de Janeiro, v. 35, n. 13, e00087318.

Casassus, J. (2019). Fundamentos da Educação Emocional. Tradução: Liz Zatz. Brasília: UNESCO, Liber Livro Editora.

Cassasus, J. (2017). Una introducción a la Educación Emocional. Revista Latinoamericana de Políticas y Administración de la Educación, n. 7 (4), p. 121-130.

Delors et al., J. (1997). Educação: um tesouro a descobrir. (Relatório para a UNESCO da Comissão Internacional sobre educação para o século XXI). Tradução: Guilherme João de Freitas Teixeira. São Paulo: Cortez.

Ekman, P. (2011). A Linguagem das Emoções: Revolucione sua comunicação e seus relacionamentos reconhecendo todas as expressões das pessoas ao redor. Tradução: Carlos Szlak. São Paulo: Editora Lua de Papel.

Faure, E. et al. (1972). Learning to be: the world of education today and tomorrow. Paris: UNESCO, 1972.

Gardner, H. (1994). Estruturas da mente: a teoria das inteligências múltiplas. Tradução: Sandra Costa. Porto Alegre: Artmed.

Gil, A. C. (2002). Como elaborar projetos de pesquisa. 4a ed. 6a reimpressão. São Paulo: Atlas.

Goleman, D. (2007). Inteligência Emocional: a teoria revolucionária que define o que é ser inteligente. Tradução: Marcos Santarrita. Rio de Janeiro: Objetiva.

Graczyk. P. et al. (2000). Criteria for Evaluating the Quality of School-Based Social and Emotional Learning Programs. In: Bar-on, R. \& Parker, J. The Handbook of Emotional Intelligence: Theory, Development, Assessment and Application at Home School, and in the Workplace. Califórnia: Jossey-Bass.

McCown et al. (1998). Self Science: the emotional intelligence curriculum. Califórnia: Six Seconds. 
Minayo, M. C. S. (1992). O Desafio do conhecimento, pesquisa qualitativa em saúde. São Paulo/ Rio de Janeiro: Hucitec/ABRASCO.

Röhr, F. (2013). Educação e espiritualidade: contribuições para uma compreensão muiltidimensional da realidade, do homem e da educação. Campinas, SP: Mercado das Letras.

Salovey, P. \& Mayer, J. D. (2004). Emotional Intelligence. In: SALOVEY, Peter.; BRACKETT, M. \& MAYER, John. Emotional Intelligence: key readings on the Mayer and Salovey Model. Nova lorque: Dude Publishing.

Severino, A. J. (2007). Metodologia do Trabalho Científico. 23. ed. rev. e atual. São Paulo: Cortez.

UNESCO. (2015). Education 2030: Incheon Declaration and Framework for Action towards inclusive and equitable quality education and lifelong learning for all. Paris: UNESCO.

UNESCO. (2013). Global Citizenship Education: An Emerging Perspective. Paris: UNESCO, 2013.

UNESCO-Santiago. (2001). Primer Estudio Internacional Comparativo sobre Lenguaje, Matematica y factores asociados, para alumnos del tercer y cuarto grado de la educación básica (PEIC).

Weissberg, R. et al. (2015). Social and emotional learning: Past, present, and future. In DURLAK, Joseph et al. Handbook of social and emotional learning: Research and practice. p. 3-19. New York: Guilford Press.

Received: 25 May 2020 | Accepted: 17 February 2021 | Published: 1 May 2021

This is an Open Access article distributed under the terms of the Creative Commons Attribution License, which permits unrestricted use, distribution, and reproduction in any medium, provided the original work is properly cited. 